\title{
Ekofilm 97
}

\author{
By Jan Uhde
}

Fall 1997 Issue of KINEMA

IT WAS NO COINCIDENCE that the fairy-tale Southern Bohemian town of Český Krumlov became the site of the 23rd Festival of Film and Video programmes on Environment (EKOFILM 97). Cesky Krumlov, which is on the UNESCO's world cultural and natural heritage list, taking over the EKOFILM from the North Moravian Ostrava which hosted the festival since its inception during the communist rule in the mid-1970s. In those difficult days this festival was, as its present director Dr. Bedřich Moldán says, one of the "rare islands of renewed and fresh normality within an abnormal world." Some people see a deeper symbolism behind EKOFILM's new home: the steel-city Ostrava (a kind of Czech Detroit), was an example of environmental devastation while Český Krumlov, a few years ago still a neglected, dilapidating town, has been undergoing a careful restoration, revealing the Sleeping-Beauty charms of its medieval architecture.

Between 9 - 12 October, filmmakers, environmentalists, media reporters and, naturally, local and international audiences, watched a programme of more than one hundred (mostly short format) films and videos, about half of them in competition, from twenty European countries and overseas. The focus was on the environment including preservation of the natural and cultural patrimony. In the associated conference presentations and discussion panels, environment researchers and media representatives were contemplating questions which are nowadays on almost everyone's mind: the global warming, ecology versus economical growth, sustainable development, clean air and water, pollution and health problems, and the role of the media in building up public awareness of these serious problems. Especially the question of the electronic communications' and Internet's role in the environmental equation stirred up the participants' minds and ignited a healthy discussion.

One of the questions which the festival's nine-member International jury had to deal with was the balance between the merits of the individual films from the professional point of view, and their filmic, or artistic expression; naturally, there were contrasting personal preferences. All in all, the quality of the presented films was high, and their artistic merits did not suffer despite the importance of their philosophical underpinnings.

The Grand Prize of EKOFILM 97 was awarded to the Czech film Harmony in Blue, by Petr Amler. This documentary on one of the internationally important Czech wetlands in the Oder-river Natural preserve was a relatively clear front-runner. The Best Direction Award went to the Freedom regained of the Danish director Bent Lauge Madsen; this quietly compassionate short popular with many viewers about bringing improperly regulated water courses to their original state, illustrated that environmental damage can be remedied if there is the necessary will to do so. A film from Slovakia, The River of Dreams, and its brilliant cameraman, Ladislav Csukas, took the Award for Best Photography. One of the Honourable Mentions of the Jury was awarded to a striking film from Northern Ireland, Talking Trees, directed by Lionel Mill.

Ekofilm is supported and organised by the Czech Ministry of Environment and the Auviex s.r.o., with participation of several other corporate sponsors, including Bohemia Crystalex, Czech Telekom, and Czech Television; last but not least, it has received an unequivocal endorsement by the Český Krumlov City Hall. It was evident that the town was proud to be the festival's host. Both the organisers and participants seemed to understand that the EKOFILM is a truly rare undertaking, and with the longest tradition: with the exception of the French-based Festival International du film d'environment (RIENA, in Paris, since 1982), there are no other film festivals exclusively devoted to this subject. Given the growing global awareness of environmental problems, EKOFILM has a good chance to prosper in the future.

\section{Author Information}

Jan UHDE is Professor Emer. (Film Studies) at the University of Waterloo, Ontario, Canada. Born in Brno, Czech Republic. Graduated (MA) from the Faculty of Arts, Masaryk University, Brno; PhD received at the 


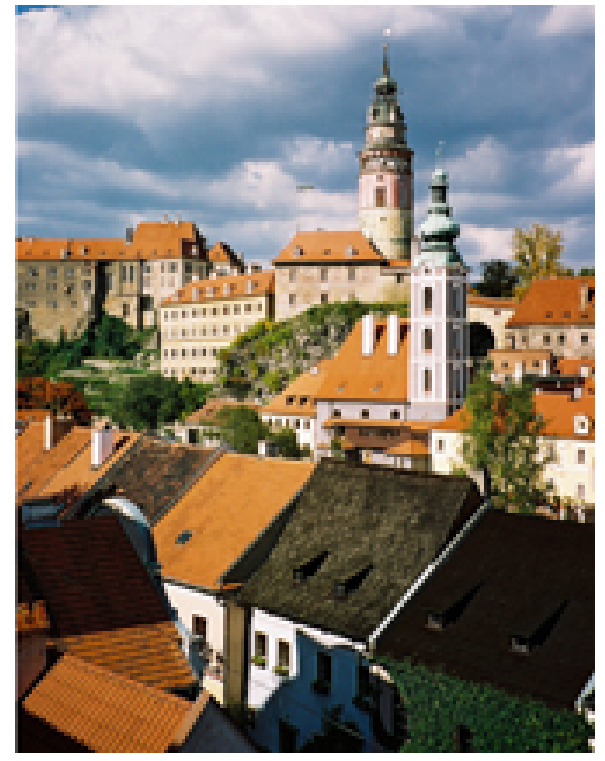

Figure 1: Český Krumlov, the new site of Ekofilm

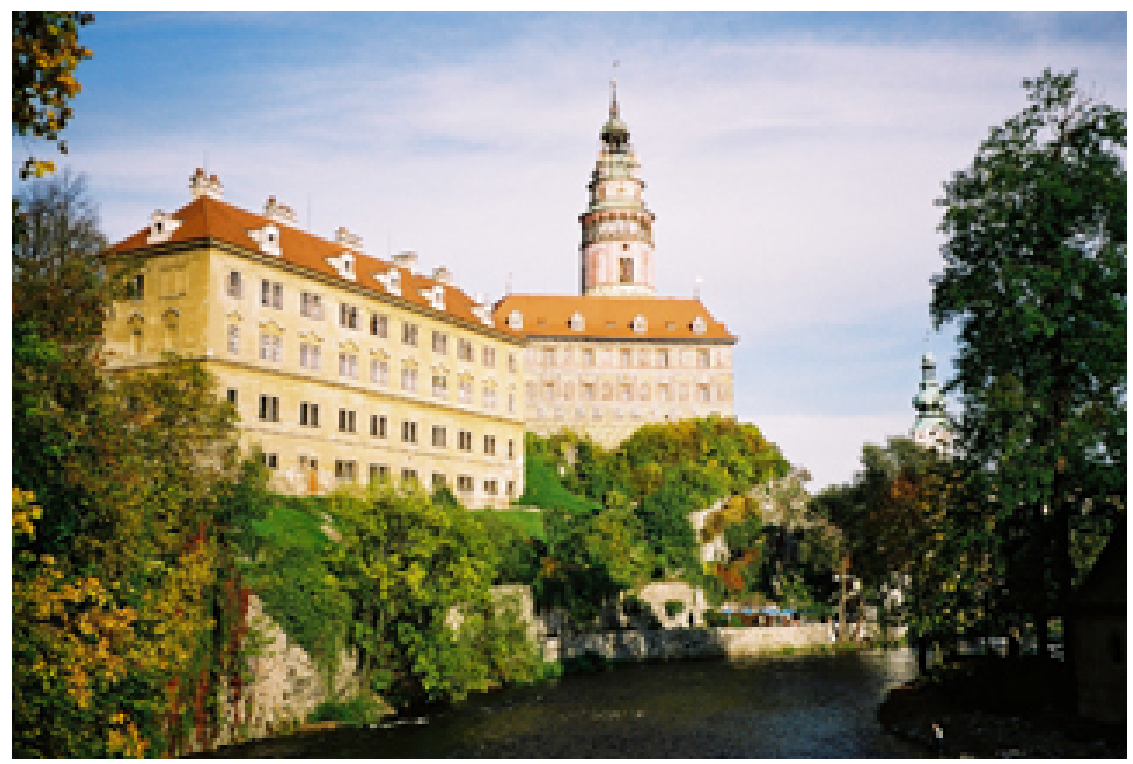

Figure 2: Český Krumlov, the new site of Ekofilm 
University of Waterloo, Ontario, Canada. He taught at the University of Waterloo (1970-2012) where he founded a General and Honours BA program in Film Studies at the Department of Fine Arts.

Publications: Latent Images: Film in Singapore Second edition, with Yvonne Ng Uhde (Ridge Books, National University Press of Singapore, 2010); Latent Images: Film in Singapore, with Yvonne Ng Uhde (Oxford University Press, 2000); Latent Images: Film in Singapore CD-ROM (2003, co-author); Vision and Persistence: Twenty Years of the Ontario Film Institute (University of Waterloo Press, 1990) and Ontario Film Institute Programming Activities Index 1969-1989 (Toronto: Ontario Science Centre, 1990). He co-edited the Place in Space: Human Culture in Landscape (Proceedings from the Second International Conference of the Working Group "Culture and Landscape" of the International Association of Landscape Ecology, Pudoc Scientific Publishers, Wageningen, Holland, 1993). Jan Uhde has published articles and reviews in several countries (including Canada, USA, Germany, Italy), participated in international juries at film festivals and presented papers at international conferences in North America and Europe. In 1998/99, he was a visiting researcher at the School for Film and Media Studies, Ngee Ann Polytechnic, Singapore.

His professional and research interests focus on Singapore cinema; the identification and distancing mechanisms of the film viewer; the non-authored modifications and manipulation of films; and specific aspects of film history, including the Central European cinema.

He founded KINEMA in 1993. 